\title{
Economic Assessment of the Total Amounts of Repayments and Defaults by Large and Small Scale Farmer Beneficiaries of Bank of Agriculture Loans from 2010-2016 in Anambra State, Nigeria.
}

\author{
Isibor, Annunciata. Chinwe $\mathrm{e}^{*} \quad$ Nkamigbo, Darlington. Chineze ${ }^{2}$ \\ 1.Department of Agricultural Economics \& Extension, Nnamdi Azikiwe University, Awka, Anambra, State, \\ Nigeria \\ 2.Department of Agricultural Technology, Anambra State Polytechnic, Mgbakwu, Anambra State, Nigeria
}

\begin{abstract}
The study examined loan repayments and defaults by large and small scale farmer-beneficiaries of Bank of Agriculture (BOA) loans from 2010-2016 in Anambra State, Nigeria. The specific objectives were to examine the total amounts of loan repayments and defaults by large and small scale farmer- beneficiaries of BOA loans and constraints militating against loan repayment/default by the farmers. A multistage sampling procedure involving purposive and random sampling methods were used to select 256 respondents for the study. Data were collected from both primary and secondary sources. Primary data were collected using two sets of questionnaire; one for the farmers and the other for the bank officials while secondary data were sourced from loan transaction records in the headquarters and branch offices of BOA in the State. Collected data were analysed by means of descriptive statistics technique. Findings on repayments indicated that more repayment, $\$ 69,533,625$ constituting $60.33 \%$ of total repayment, was made by the large scale farmers on livestock and fisheries enterprises than the $\$ 33,384,988$ or $46.71 \%$ of the repayment made by the small scale farmers on the loans they obtained for similar enterprises. The small scale farmers' major (53.29\%) repayment was on cropping enterprises while the large scale farmers preferred to spend a smaller percentage (39.67\%) of their repayments on cropping enterprises. Comparatively, rate of default was higher $(60.33 \%)$ for livestock and fisheries enterprises of the large scale farmers than the $46.76 \%$ of the small scale farmers. However, rate of default by the small scale farmers, $53.24 \%$, was higher for the cropping enterprises that the $39.67 \%$ rate of default recorded by the large scale crop farmers. Poor returns from sale of product and low market price for product were the major constraints. Government through the central Bank should consider reducing cost of lending for agricultural enterprises by lowering the interest rate further and BOA should ensure that disbursements meet up with appraisal amounts in the business plans of the farmers to avoid uncompleted and failed projects were recommended.
\end{abstract}

Keywords: Economic, Loan, Repayment and Default

DOI: $10.7176 / \mathrm{JNSR} / 9-16-06$

Publication date: August $31^{\text {st }} 2019$

\section{Introduction}

The agricultural sector is an engine room for sustaining growth of Nigeria economy and still remains the mainstay of the economy of most African States (Olosunkanmi, Afolabi and Daramola, 2012 and Nkamigbo, 2018). The primary place agriculture occupies in providing food and fibre for the people has made it the most single factor in influencing the standard of living of many people in developing countries, particularly Nigeria (Chigbu, 2005; Olagunjiu and Adeyamo, 2007; Akande, Soma and Namen, 2008).

According to Lawal and Ette (2006), the sector accounted for well over $80 \%$ of the export earnings and about $50 \%$ of government revenue in the 1960 s prior to the discovery of crude oil. Unfortunately, over the years the sector has witnessed tremendous decline in its contribution to the national output. Currently, agriculture is contributing about $42 \%$ of the gross domestic product (GDP) of Nigeria (Central Bank of Nigeria (CBN), 2011). One of the reasons for decline in the contributions of agriculture to the economy of Nigeria is lack of a stable National Credit policy and paucity of credit institutions which can assist farmers (Afolabi, 2010; Nwachukwu and Alamba, 2010).

Credit is a crucial factor in the development of the rural sector. One of the major inputs identified over the years in the development of the Nigerian agricultural sector has been the agricultural credit (CBN, 2005). Access to credit facilities of these poor rural people has the potential of making the difference between eradicating poverty and securing life economically as well as enhancing agricultural productivity (Zeller, 1998). One of the problems confronting farmers and consequently agricultural productivity and growth in Nigeria is inadequate capital despite the glaring contributions of agricultural sector in the overall economic development of the country (Odoemenam and Obinne, 2010). For instance, agricultural credit in Nigeria as a percentage of banks' total credit was $1.4 \%$ in 2008 and has averaged $2.5 \%$ over the last few years. Agricultural credit is closely related to providing needed resources, which most farmers cannot source from their personal savings. In this regard, the 
provision of credit has to be made a vital way of promoting agricultural development in Nigeria.

Besides access to loans and disbursement of loans, the level of loan repayment and loan default is also very important. Loan repayment is the act of paying back money previously borrowed from a lender. Repayment usually takes the form of periodic payments that normally include part principal plus interest in each payment. Loan default is the failure to pay interest or principal on a loan or security when due. It occurs when a lender is unable to meet the legal obligation of debt repayment.

\section{Material and Methods}

The study was carried out in Anambra State of Nigeria. The state consists of twenty-one (21) Local Government Areas (LGA) and four agricultural zones namely, Aguata, Anambra, Awka and Onitsha. The State is located between latitudes 60451 and $50441 \mathrm{~N}$ and longitudes 60361 and $70291 \mathrm{E}$. It has a population of 4,182,032 (NPC, 2006). The number of farm families is 338,721 with an average size of eight persons per farm family or household (Anambra State Economic Empowerment Development Strategy (S.E.E.D.S) 2006).

Agriculture is the predominant occupation in the rural areas engaging more than $70 \%$ of the rural population. Both the large and small scale farmers in the area have benefitted from credit facilities of the Bank of Agriculture (BOA) for the various crops, livestock and fisheries production activities. This was possible because of the existence of the bank's branch offices in the three Senatorial zones of the State, as well as ease of accessibility to credit facilities of the bank by the farmers from the headquarters strategically located at the centre of Awka, the capital city of Anambra State.

\subsection{Population and Sampling Procedure}

The study population comprised all farmers who have benefited from the BOA credit facilities in Anambra State of Nigeria and staff of the BOA branch offices in Awka. Nteje, Oko and Ukpo. Multistage, purposive and simple random techniques were used to select four agricultural zones, 12 LGAs, 240 (120 large scale and 120 small scale) farmer-beneficiaries of BOA credit facilities and 16 BOA staff for the study.

Stage 1: The four Agricultural zones were purposively selected because of the existence of an office of the BOA in the zones. At stage II, three LGAs were randomly selected from each of the selected agricultural zones to arrive at 12 LGAs. Stage III witnessed the random selection of five large scale and five small scale farmerbeneficiaries of the bank's loans from each of the 12 selected LGAs to arrive at a total of 240 respondents (120 large scale farmers and 120 small scale farmers). In addition, 16 of the Bank of Agriculture staff will be selected randomly for information on loan administration by BOA to arrive at a grand total of 256 respondents.

\subsection{Method of Data Collection}

Data were collected from both primary and secondary sources and primary data were collected using two sets of questionnaires, one for the farmers and the other for the bank officials. Secondary data were sourced from the headquarters and branch offices of the BOA in the State. Descriptive statistical tools such as means, frequency counts and percentages were used the achieve objectives. Constraints to loan repayment/default and loan administration: A 4-point Likert type scale was used to collect data on constraints to loan repayment/default and loan administration. Responses from the respondents were scored as follows; very serious $=4$, serious $=3$, moderately serious $=2$, and not serious $=1$. Determination of cut-off point was done as:

$\mathrm{X}=\sum_{n}^{\frac{f}{4}}=\frac{4+3+2+1}{4}=\frac{10}{4}=2.50$.

To make inferential statement, the mean score was compared with the critical mean (2.50). If the calculated mean of a problem was greater than the standard critical value then that problem was regarded as very serious.

\section{Result and Discussion}

3.1 Repayments by the Large and Small Scale Farmer-beneficiaries of BOA Credit Facilities:

Table 1: Repayments to the large and small scale farmer-beneficiaries of BOA loans (2010-2016)

\begin{tabular}{|c|c|c|c|c|c|c|}
\hline \multirow[t]{2}{*}{ Enterprise } & \multicolumn{2}{|c|}{ Large Scale Farmers } & \multicolumn{2}{|c|}{ Small Scale Farmers } & \multicolumn{2}{|c|}{ Large \& Small Scale } \\
\hline & Amount (N) & $\%$ of Total & Amount (\#) & $\%$ of Total & Amount (N) & $\%$ of $\mathrm{T}$ \\
\hline Crops & $45,728,775$ & 39.67 & $38,086,230$ & 53.29 & $83,815,005$ & 44.88 \\
\hline \multicolumn{7}{|l|}{ Livestock: } \\
\hline Poultry & - & - & $24,095,370$ & 33.71 & - & - \\
\hline Piggery & - & - & $2,844,855$ & 3.98 & - & - \\
\hline Fisheries & & & $6,444,713$ & 9.02 & & \\
\hline Livestock \& Fisheries & $69,533,625$ & 60.33 & $33,384,988$ & 46.71 & $102,918,613$ & 55.12 \\
\hline Total & $115,262,400$ & 100.00 & $71,471,218$ & 100.00 & $186,733,618$ & 100.00 \\
\hline
\end{tabular}

Source: Field survey, 2017. Note: $T=$ Total.

Table 1 shows result of data analysis on the repayments made by the large and small scale farmer- 
beneficiaries of the BOA loans for crops, livestock and fisheries enterprises from 2010 to 2016. The result showed that more repayment, N69,533,625 constituting $60.33 \%$ of total repayment, was made by the large scale farmers on livestock and fisheries enterprises than the N33,384,988 or $46.71 \%$ of the repayment made by the small scale farmers for the loans they obtained for similar enterprises. The small scale farmers' major (53.29\%) repayment was on cropping enterprises while the large scale farmers preferred to spend a smaller percentage $(39.67 \%)$ of their repayments on cropping enterprises. This implies that, higher the amount of loan disbursed for capital intensive enterprises (livestock and fisheries), higher the repayments expected from them. This result corroborates Kuye (2015) who recorded a higher repayment rate of $97 \%$ for large scale farmers than small scale farmers.

3.2 Defaults by the Large and Small Scale Farmer-beneficiaries of BOA Credit Facilities:

The distribution of defaults among the enterprises embarked upon by the large and small scale farmerbeneficiaries of the BOA loans is shown in Table 2

Table 2: Defaults by the large and small scale farmer-beneficiaries of BOA loans (2010-2016)

\begin{tabular}{|l|l|l|l|l|l|l|}
\hline \multirow{2}{*}{ Enterprise } & \multicolumn{2}{l|}{ Large Scale Farmers } & \multicolumn{2}{l|}{ Small Scale Farmers } & \multicolumn{2}{l|}{ Large \& Small Scale } \\
\cline { 2 - 7 } & Amount (N) & \% of Total & Amount (\#) & \% of Total & Amount (N) & \% of T \\
\hline Crops & $228,096,225$ & 39.67 & $50,407,770$ & 53.24 & $278,503,995$ & 41.59 \\
\hline Livestock: & & & & & & \\
\hline Poultry & - & - & $31,890,630$ & 33.68 & - & - \\
\hline Piggery & - & - & $2,573,145$ & 2.72 & - & - \\
\hline Fisheries & & & $9,809,287$ & 10.36 & & \\
\hline Livestock \& Fisheries & $346,841,375$ & 60.33 & $44,273,012$ & 46.76 & $391,114,387$ & 58.41 \\
\hline Total & $574,937,600$ & 100.00 & $94,680,782$ & 100.00 & $669,618,382$ & 100.00 \\
\hline
\end{tabular}

Source: Field survey, 2017. Note: T = Total.

Result indicated that grand default for the enterprises sponsored with the loans obtained by both the large and small scale farmers was much higher (N669,618,382 or 78.19\%) than the N186,733,618 constituting only $21.81 \%$ of the grand repayment made by pooled large and small scale farmers. Comparatively, rate of default was higher $(60.33 \%)$ for livestock and fisheries enterprises of the large scale farmers than the $46.76 \%$ of the small scale farmers. However, rate of default by the small scale farmers, 53.24\%, was higher for the cropping enterprises that the $39.67 \%$ rate of default recorded by the large scale crop farmers. Adejobi and Atobatele (2008) reported high default rate of about $77 \%$ among small scale farmers in south western Nigeria.

3.3 Differences between Repayments and Defaults by the Large and Small Scale Farmers:

The result of test of hypothesis of no significant differences between repayment made by the large and small scale farmers and defaults by the large and small scale farmers is shown in Table 3.

Table 3: Test of hypotheses about differences between applications, repayments and defaults by the large and small scale farmers

\begin{tabular}{|l|l|l|l|l|}
\hline Pairs of loan group & $\mathrm{N}$ & Mean & Differences between Means & T-ratio \\
\hline LSFA & 120 & $16,266,667$ & & \\
\hline SSFA & 120 & $10,948,875$ & $5,325,792$ & $34.57^{* * *}$ \\
\hline LSFD & 120 & $5,751,667$ & & \\
\hline SSFD & 120 & $1,384,600$ & $4,367,067$ & $19.49^{* * *}$ \\
\hline LSFR & 120 & 960,520 & & \\
\hline SSFR & 120 & 595,593 & 364,926 & $2.15^{* *}$ \\
\hline LSFD & 120 & $4,791,146$ & & $12.36^{* * *}$ \\
\hline SSFD & 120 & 789,006 & $4,002,139$ & \\
\hline
\end{tabular}

Source: Field survey, 2017.

It could be seen from the result that there were significant differences between repayments of the large and small scale farmers at 5\% level of significance, and between the defaults by large and small scale farmers at $1 \%$ probability level. In each case the large scale farmers were favoured. This implies higher the amount of credit applied for by the bank's customer, higher the expected disbursement, repayment and most likely default. Chiekezie, Omokere, Akpoko and Chikarie (2012) reported high default rates among the male and female cooperative farmer-beneficiaries of Bank of Agriculture micro loans. 


\section{Constraints to Loan Repayments by the Farmers}

Table 4: Problems militating against loan repayment by the farmers

\begin{tabular}{|l|l|l|}
\hline Problem & Mean Score & Rank \\
\hline Poor returns from sale of product & 3.84 & $1^{\text {st }}$ \\
\hline Low market price for product & 3.67 & $2^{\text {nd }}$ \\
\hline Family commitment & 3.54 & $3^{\text {rd }}$ \\
\hline Delay in loan disbursement & 2.42 & $4^{\text {th }}$ \\
\hline High cost of production & 2.21 & $5^{\text {th }}$ \\
\hline High interest rate & 1.98 & $6^{\text {th }}$ \\
\hline Pest and disease attacks & 1.62 & $7^{\text {th }}$ \\
\hline
\end{tabular}

The large and small scale farmer-beneficiaries of BOA loans encountered many challenges in repaying the facilities. The challenges arranged in descending order of seriousness were poor returns from sale of product (M =3.84), low market price for product $(\mathrm{M}=3.67)$, family commitment $(\mathrm{M}=3.54)$, delay in loan disbursement $(\mathrm{M}$ $=2.42)$, high cost of production $(\mathrm{M}=2.21)$, high interest rate $(\mathrm{M}=1.98)$, and pest and disease attacks $(\mathrm{M}=$ 1.62). Isibor, (2018) asserted that family commitments (like school fees, extended family problems, burials and other non-farm burdens on the respondents) as well as low market prices, especially during harvest period, occasioned mainly from poor storage facilities.

\section{Summary and Conclusion}

Based on the findings, the following conclusion were arrived at, Proportionate repayment by the large scale farmers was by far lower than that of the small scale farmers, hence cumulative default by the large scale farmers was higher than that of the small scale farmers.

The small scale farmers' major (53.29\%) repayment was on cropping enterprises while the large scale farmers preferred to spend a smaller percentage $(39.67 \%)$ of their repayments on cropping enterprises. Comparatively, rate of default was higher $(60.33 \%)$ for livestock and fisheries enterprises of the large scale farmers than the $46.76 \%$ of the small scale farmers. However, rate of default by the small scale farmers, $53.24 \%$, was higher for the cropping enterprises that the $39.67 \%$ rate of default recorded by the large scale crop farmers. More enlightenment campaigns should be provided by government through the extension agents to train the less educated farmers on procedure for documentations for the BOA loans, need for the provision of accurate data and modern technologies that will improve their access, utilization, repayment, and minimize defaults. Government should engage more skilled staff and provide adequate logistics to ensure timely credit transactions, better monitoring of beneficiaries projects and improved recovery of lent fund. The beneficiaries should explore adding value to their products and reaching out to distant markets so as to get better prices for their products, realize more income and improve repayment rate were recommended.

\section{References}

Adejobi, O. \& Atonatele, J.T. (2008). An analysis of loan delinquency among small scale farmers in south western Nigeria: Application of logit and loan performance indices. East African Agricultural and Forestry Journal, 74(3).

Afolabi, J.A. (2010). "Analysis of loan repayment among small scale farmers in Oyo state" Journal of Social Sciences, 22(2), 115-119.

Akande, O.R., Soma, J.T. \& Nasmen, A.A. (2008). “An investigation into the complementariness between postharvest and production credit under the NACRDB agricultural credit program in Makurdi zone of Benue state". FAMAN 22 annual conference, 102-166.

Central Bank of Nigeria (2005). Agricultural Credit guarantee scheme fund in Nigeria (ACGSF): an impact assessment. Study conducted by center for research analysis and management for the governing board of the ACGSF, Abuja

Central Bank of Nigeria (2011). Monetary, Credit, Foreign Trade and Exchange Policy Guidelines for Fiscal Years 2010/2011 (Monetary policy circular No.38)

Chikezie NP, Omokore DF, Akpoko JG, Chikaire J (2012). Factors influencing rural youth adoption of cassava recommended production practices in Onu-Imo Local Government Area of Imo State, Nigeria. Greener J. Agric. Sci, 2(6), 259-268.

Chigbu, U.E. (2005). "The case of agriculture as the only savior to the Nigerian dying economy" Retrieved July 10 th 2016 from www.nigeriawillagesquare.com

Isibor,. A.C. (2018). ' Comparative study of loan repayment and default by farmer-beneficiaries of bank of agriculture loans in Anambra State, Nigeria.Unpublished Ph. D Thesis Department of Agricultural Economics and Extention, Chukwuemeka Odumegwu Ojukwu University, Igbariam Campus. Anambra 
State.

Lawal, A.M. \& Ette, O.A. (2006). "Analysis of agricultural production in Nigeria" African Journal for Agricultural Research, 2(1), 20-36.

Nwachukwu, I.N., Alamba, C.S. \& Oko-Isu, A. (2010). "Determinant of institutional credit repayment performance among farmers in Afikpo North LGA of Ebonyi State, Nigeria" AAB BIOFLUX, 2(3), 211226.

National Population Commission (2006). Population Census Report National Population Commission of Nigeria, Abuja.

Nkamigbo. D.C. (2018). ' Economics of watermelon marketing in Anambra State, Nigeria. Unpublished Ph. D Thesis Department of Agricultural Economics and Extension, Chukwuemeka Odumegwu Ojukwu University, Igbariam Campus. Anambra State.

Odoemenam, I.U. \& Obinne, C.O. (2010). Assessing the factors influencing the utilization of improved cereal crop production technologies by small scale farmers in Nigeria. Retrived July 10th 2016 from www.indjust.org/archive/vol.3.issue2/innocent-17.pdf

Olagunji, F.I. \& Adeyemo, R. (2007). "Determinants of repayment decision among small holder farmers in south western Nigeria" Pakistan Journal of Social sciences, 4(5),677-686.

Olasunkamni, B. B, Afolabi, M. and Daramola, F. (2012). Enterprise combination in Cassava-Based food crop farming system in Nigeria: Evidence from Ogun State. Greener Journal of Agricultural Science, 2(1), 13-20.

Zeller, M. \& Sharma, M. (1998). Rural financial services for poverty alleviation. 